\title{
An exposure and risk assessment for fluoride and trace metals in black tea
}

\author{
Sait C. Sofuoglu*, Pınar Kavcar ${ }^{1}$ \\ İmir Institute of Technology, Department of Chemical Engineering and Environmental Research Center, \\ Gülbahçe, Urla 35430 İzmir, Turkey \\ Received 22 June 2007; received in revised form 28 December 2007; accepted 26 January 2008 \\ Available online 6 February 2008
}

\begin{abstract}
Exposure and associated health risks for fluoride and trace metals in black tea were estimated. Fifty participants were randomly recruited to supply samples from the tea that they drink, and self-administer a questionnaire that inquired about personal characteristics and daily tea intake. Analyzed trace metals included aluminum, arsenic, barium, cadmium, cobalt, chromium, copper, manganese, nickel, strontium, and zinc. Fluoride and four metals (Al, Cr, Mn, Ni) were detected in all samples while barium was detected only in one sample. The remaining metals were detected in $>60 \%$ of the samples. Fluoride and aluminum levels in instant tea bag samples were greater than in loose tea samples $(p<0.05)$ while the differences in elemental concentrations of loose and pot bag tea samples were not significant. Median and 90th percentile daily tea intake rates were estimated as 0.35 and 1.1 1/day, respectively. Neither fluoride nor aluminum levels in black tea were found to associate with considerable risks of fluorosis and Alzheimer's disease, respectively. However, carcinogenic risk levels for arsenic were high; $R>1.0 \times 10^{-6}$ even at the median level. According to sensitivity analysis, daily tea intake was the most influencing variable to the risk except for arsenic for which the concentration distribution was of more importance.
\end{abstract}

(C) 2008 Elsevier B.V. All rights reserved.

Keywords: Black tea; Aluminum; Arsenic; Fluorosis; Alzheimer's disease

\section{Introduction}

Elemental content of tea may have both beneficial and adverse effects on human health. While beneficial effects were investigated against cancer [1,2], vascular diseases [3], hypertension [4], and dental caries [5], tea was associated with dental [6] and skeletal [7] fluorosis, and Alzheimer's disease [8] due to accumulation of fluoride (F) and aluminum (Al), respectively, in the plant. The impact of tea drinks on human health has been observed, and trace elemental content of tea has been investigated in Southern Asian countries where tea is a traditional drink consumed in large quantities, such as in China [9], India [10], Taiwan [11], and Tibet [6] for fluoride, and in China [12], and Thailand [13] for aluminum and other trace elements. Recently,

\footnotetext{
* Corresponding author. Tel.: +90 232750 6648; fax: +90 2327506645 . E-mail addresses: cemilsofuoglu@iyte.edu.tr, saitcemil@iit.edu (S.C. Sofuoglu),pinarkavcar@iyte.edu.tr (P. Kavcar).

${ }^{1}$ Tel.: +90 232750 6670; fax: +90 2327506645 .
}

infusion fluoride concentrations of up to $6.5 \mathrm{mg} / 1$ [7] and brand name bottled tea concentrations of up to $4.1 \mathrm{mg} / \mathrm{l}$ [14] were measured in the US.

Aluminum is liberated from the aluminosilicate fraction of soil clays in acidic conditions, under which $\mathrm{F}-\mathrm{Al}$ complexes can be formed [12], which leads to their elevated uptake by the tea plant. Transported to the leaves, they both can be accumulated at large quantities. Shu et al. [15] reported that $\mathrm{Al}$ and $\mathrm{F}$ contents were higher in older tea leaves, which was also associated with lower tea quality [16]. Higher F levels were measured in infusions of instant black tea bags than of granular and stick shaped black tea [18]. In fact recently, skeletal fluorosis diagnosed on an American patient was found to be associated with her long-term intake of instant tea in large quantities [7]. While almost all the fluoride could be infused into water [17], transfer ratio from tea product to liquor was estimated as $0.34-0.58$ for aluminum [12]. Fluoride concentration in tea infusions may be up to $6.1 \mathrm{mg} / \mathrm{l}$ for instant black tea bags [18], and $7.3 \mathrm{mg} / \mathrm{l}$ for brick tea after 6-h infusion [19]. Infusion aluminum concentrations were reported as $0.7-3.5 \mathrm{mg} / 1$ [12] but might be up to $6 \mathrm{mg} / 1$ [19]. 
Turkish people are, also traditionally, a black tea drinking population throughout the day. Fluoride content of black tea marketed in Turkey was the subject of several investigations. While $\mathrm{F}$ content of tea leaves was found to range between 67 and $289 \mathrm{mg} / \mathrm{kg}[20,21]$, infusion concentrations ranged from 0.64 to $3.92 \mathrm{mg} / \mathrm{l}[17,20]$. Content of black tea other than F was studied [22] only for cadmium and vanadium (mean concentrations of two types of tea were reported as 2.79 and $4.39 \mathrm{mg} / \mathrm{kg}$ for cadmium, and 0.65 and $2.30 \mathrm{mg} / \mathrm{kg}$ for vanadium). However, manganese, iron, copper, zinc, and nickel were measured in green tea as $1610,342,32,28$, and $26 \mathrm{mg} / \mathrm{kg}$, respectively [23]. Kalayci and Somer [17] estimated a daily $F$ intake range of $0.46-0.98 \mathrm{mg} / \mathrm{day}$ for different brands of black tea and various infusion times. Tokalioglu et al. [20] concluded that, excluding intake from other sources, high-end daily tea consumption may result in dental fluorosis.

Because Turkish people habitually drink black tea, an exposure and risk assessment for trace elements in tea was deemed necessary as this information were not available in the literature. The objectives of this study were to determine (1) fluoride and trace metal infusion concentrations, especially aluminum, in black tea consumed by İzmirians, (2) daily tea consumption rate of İzmir population, and (3) associated exposure and health risk levels.

\section{Materials and methods}

\subsection{Questionnaire}

A questionnaire was composed to determine daily tea intake. The questionnaire acquired the consumption rate in different cup types as number of glasses drunk in a day. Turkish people traditionally drink tea in small $(75 \mathrm{ml})$, special tea glasses. However, two types of tea cups $(100$ and $150 \mathrm{ml})$ are also popular. The largest cups are in the size of $250 \mathrm{ml}$. The consumption rates were then converted to liters per day. The participants self-administered the questionnaire, and provided duplicate samples from the tea they consumed. The questionnaire also acquired information about the provided tea sample including brand of the tea and how it was consumed (by brewing in a pot, instant in a cup). Other key data obtained by the questionnaire are personal information on the participant, i.e., body weight, sex, year of birth, etc. Fifty participants were randomly recruited, taking population age distribution into account.

\subsection{Sample preparation}

All beakers and HDPE bottles were kept in 20\% nitric acid (Merck) bath for $2 \mathrm{~h}$ and dried in a hood. Two grams of tea were weighed from each sample. Two hundred milliliters of boiling ultra-pure water (Millipore Elix5) were added to each sample in a beaker, and infused for $15 \mathrm{~min}$. At the end of the infusion period, the tea drink was filtered into two 60-ml HDPE bottles (one for $\mathrm{F}$ analysis and one for trace metal analysis) and cooled to room temperature. Trace metal samples were acidified to $\mathrm{pH}<2$ with the addition of ultra pure nitric acid (Fluka). All samples were stored at $+4{ }^{\circ} \mathrm{C}$ in a refrigerator until analysis; for a maximum of 2 days for $\mathrm{F}$ analysis.

\subsection{Fluoride analysis}

Fluoride analysis was performed using a Corning model 450 digital $\mathrm{pH} /$ ion meter in conjunction with Cole-Parmer fluoride electrode. Total ionic strength adjustment buffer (TISAB) solution was prepared. To prepare the TISAB solution $28.5 \mathrm{ml}$ glacial acetic acid, $29 \mathrm{~g} \mathrm{NaCl}$, and $2 \mathrm{~g}$ of a chelating agent (CDTA, 1,2-cyclohexylene dinitrilo tetraacetic acid) were added to approximately $250 \mathrm{ml}$ distilled water in a 500-ml beaker, and stirred to dissolve the materials. The solution was completed to $500 \mathrm{ml}$ by adding $5 \mathrm{M}$ sodium hydroxide, resulting in a solution with a $\mathrm{pH}$ of 5.0-5.5. The TISAB solution regulates the ionic strength of samples and standard solutions, and adjusts the $\mathrm{pH}$. It also avoids interferences by polyvalent cations such as $\mathrm{Al}(\mathrm{III})$, $\mathrm{Fe}(\mathrm{III})$, and $\mathrm{Si}(\mathrm{IV})$ that are able to complex or precipitate with fluoride, and reduce the free fluoride in the solution [20].

A series of fluoride standards were prepared by using $10 \mathrm{ppm}$ F standard solution in the range of $0-10 \mathrm{mg} / \mathrm{l}$ by diluting appropriate volumes to $50 \mathrm{ml}$. Then, the electrode was calibrated to concentrations of $0.0,0.5,1.0,2.0,5.0$ and $10.0 \mathrm{mg} / \mathrm{l}$. For every $15 \mathrm{ml}$ sample, $15 \mathrm{ml}$ TISAB solution was added in a 50$\mathrm{ml}$ beaker. The content was stirred at medium speed for $5 \mathrm{~min}$ using a magnetic stirrer. The fluoride electrode was immersed in the stirred solution. When taking measurements, the electrode was remained in solution until the apparatus gave a signal and the potential $(\mathrm{mV})$ was read. Calibration curve for potentiometric determination of fluoride was drawn after reading the potentials. The mean blank level was $0.163 \mathrm{mg} / \mathrm{l}(n=3)$ for the experiment. The blank value was subtracted from sample readings.

\subsection{Trace metal analysis}

Inductively coupled plasma-mass spectrometry measurements were performed by a quadruple Agilent 7500ce spectrometer equipped with Octapole Reaction System (ORS). A glass concentric nebulizer (Glass Expansion, MicroMist Nebulizer) with a Peltier-controlled quartz spray chamber was used as the sample introduction system. The ShieldTorch System (STS) was used to obtain cool plasma. Calibration was performed with external standards. Instrumental operating conditions were as follows: RF generator frequency $27 \mathrm{MHz}$, power output $1500 \mathrm{~W}$, argon flow rate: plasma $15 \mathrm{l} / \mathrm{min}$, auxiliary $11 / \mathrm{min}$, carrier $11 / \mathrm{min}$, nebulizer $0.08 \mathrm{rps}$. Solution uptake rate $0.3 \mathrm{rps}$, interface: nickel sampler $(1 \mathrm{~mm}$ i.d.) and skimmer ( $0.4 \mathrm{~mm}$ i.d.) cones. Data acquisition: peak hopping, dwell time $100 \mathrm{~ms}$, number of replicates 3. Analytical masses: ${ }^{27} \mathrm{Al},{ }^{52} \mathrm{Cr}$, ${ }^{55} \mathrm{Mn},{ }^{58} \mathrm{Ni},{ }^{59} \mathrm{Co},{ }^{63} \mathrm{Cu},{ }^{66} \mathrm{Zn},{ }^{75} \mathrm{As},{ }^{88} \mathrm{Sr},{ }^{111} \mathrm{Cd},{ }^{137} \mathrm{Ba}$. Ultrapure water (Millipore Elix5), spiked with known concentrations of the 11 elements, was put through the extraction and analysis procedure for recovery assessment $(n=3)$. The mean recovery values were ranged from $96 \%$ for $\mathrm{Al}$ to $110 \%$ for $\mathrm{Zn}$. Overall, recovery was $103 \pm 1.7 \%$ (mean \pm S.D.). Three blanks were also analyzed. The mean blank levels were $<0.5 \%$ of the mean 
sample concentrations for all elements, except for Cd which was $3.5 \%$.

\subsection{Exposure and risk estimation}

In this study, exposure from ingestion of tea was assessed. In order to estimate the daily exposure of an individual, the US Environmental Protection Agency, USEPA [24] suggests the lifetime average daily dose (LADD) as the exposure metric. The following equation is a similar representation of daily exposure for ingestion route modified from the USEPA [25]:

$\mathrm{CDI}=\frac{C \times \mathrm{DI}}{\mathrm{BW}}$,

where CDI is the chronic daily intake $(\mathrm{mg} /(\mathrm{kg} \mathrm{d})), C$ is the contaminant concentration in tea infusion $(\mathrm{mg} / \mathrm{l})$, DI is the average daily intake rate of tea (1/day), and BW is body weight $(\mathrm{kg})$. Multiplication of $C$ and DI is daily fluoride intake ( $\mathrm{mg} /$ day). Values of these three input variables, specific to each participant, were used to estimate the subject's individual chronic daily exposure level.

Lifetime cancer risk associated with ingestion exposure was calculated using the following equation [26,24]:

$R=\mathrm{CDI} \times \mathrm{SF}$,

where $R$ is the probability of excess lifetime cancer (or simply risk), CDI is the chronic daily intake ( $\mathrm{mg} /(\mathrm{kg}$ day $)$ ), and SF is the slope factor of the chemical $(\mathrm{mg} /(\mathrm{kg} \text { day }))^{-1}$.

The hazard quotient (HQ) was calculated to estimate noncarcinogenic risk using the following equation [27]:

$\mathrm{HQ}=\frac{\mathrm{CDI}}{\mathrm{RfD}}$,

where RfD is the reference dose (mg/(kg day)). An HQ value of $\gg 1$ implies a significant risk level.

SF and RfD values employed in this study were obtained from the USEPA [28]. In addition to the individual assessment, population exposure-risk assessment was carried out for each element using Monte Carlo simulation described in the next section.

\subsection{Statistical methods}

Concentration data were censored for non-detects to avoid overestimation of exposure and risk. A robust method was used to censor the data. Probability distributions were fitted to the detected concentrations of contaminants with $>50 \%$ detection ratio, then values were generated for the non-detects by extrapolating below the detection limit. Generated concentrations were then used in exposure and risk calculations along with the measured concentrations. Statistical analyses were performed using SPSS (Release 12.0); Monte Carlo simulations were performed using Crystal Ball (v 4.0e) software. Monte Carlo simulation is a computer-based method of analysis that uses statistical sampling techniques in obtaining a probabilistic approximation to the solution of a mathematical equation or a model [29]. Exposure and risk distributions of İzmir population were estimated using the simulated values $(n=10,000)$. One-way ANOVA test and $t$ test were used to compare the means of different groups when underlying distribution was normal. Otherwise, Kruskal-Wallis and Mann-Whitney tests were used to determine whether the infusion contaminant concentrations and risks associated with exposure to these contaminants differed across groups such as tea type and tea brand. However, the samples sizes of the subgroups were small in some instances; so the data were pooled to alleviate the effect of this drawback when it is possible. In this study, $p$-values $<0.05$ were considered to point a significant difference between the compared groups.

\section{Results and discussion}

There are various sources of trace elements such as food, drinking water, etc. Some of the sources are critical for exposure to individual elements, as in the case of toothpaste, fluoridated drinking water, and tea for fluoride, and anti-acid tablets, dietary intake, tea, and alum-treated drinking water for aluminum. In this study, black tea samples were collected and infused in ultra pure water to single out the exposure from tea. Therefore, the estimated risk levels are solely for the exposure from black tea, not accounting exposures from any other sources.

\subsection{Questionnaire data}

Randomly recruited 50 people, ranging from 8 to 79 years old, participated in the study. The mean age of the participants was 35. Characteristics of the participants are presented in Table 1. The majority of the participants brewed loose tea in a pot with tap water, and indulged in three brands. Participant daily tea intake and body weight distributions are shown in Fig. 1. Body weights of the participants were normally distributed, which ranged from 20 to $114 \mathrm{~kg}$. Daily tea intake ranged
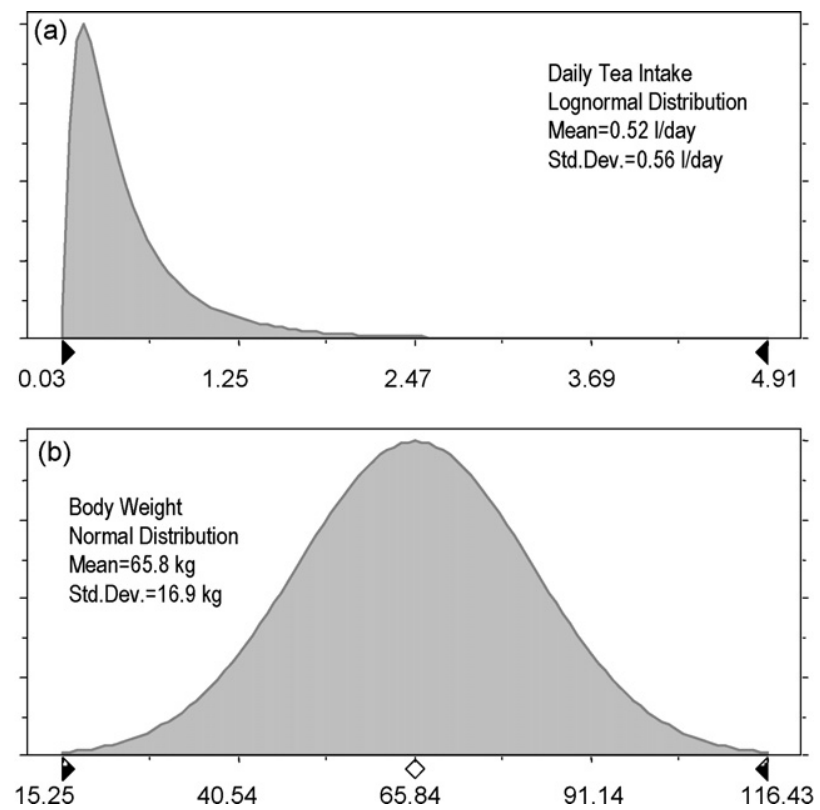

Fig. 1. Distributions of daily tea intake and body weight. 
Table 1

Characteristics of the study participants

\begin{tabular}{|c|c|}
\hline & $\%$ \\
\hline \multicolumn{2}{|l|}{ Sex } \\
\hline Female & 56 \\
\hline Male & 44 \\
\hline \multicolumn{2}{|l|}{ Age } \\
\hline $8-22$ & 26 \\
\hline $23-35$ & 34 \\
\hline $36-55$ & 24 \\
\hline $56-79$ & 16 \\
\hline \multicolumn{2}{|l|}{ Education } \\
\hline $\mathrm{NA}^{\mathrm{a}}$ & 6 \\
\hline Primary school & 22 \\
\hline High school & 40 \\
\hline College & 18 \\
\hline Graduate & 14 \\
\hline \multicolumn{2}{|l|}{ Tea type } \\
\hline Loose & 76 \\
\hline Instant bag & 12 \\
\hline Pot bag & 12 \\
\hline \multicolumn{2}{|l|}{ Tea brand } \\
\hline Caykur & 32 \\
\hline Lipton & 26 \\
\hline Dogus & 16 \\
\hline Deren & 8 \\
\hline Sir Winston & 4 \\
\hline Berk & 4 \\
\hline Import & 4 \\
\hline Others & 6 \\
\hline \multicolumn{2}{|l|}{ Water source } \\
\hline Tap & 68 \\
\hline Bottle & 30 \\
\hline Other & 2 \\
\hline
\end{tabular}

${ }^{a}$ No answer.

between 0.075 and $1.251 /$ day; lognormal distribution best fitted the intake data. The estimated mean daily tea intake in this study (0.491/day) is about half the assumed consumption by Kalayci and Somer [17], but it is approximately three times higher than Fernandez et al. [30] assumption. Nevertheless, it is much less than the consumption rates (0.8-0.91/day) in Southern Asia $[11,18]$.

\subsection{Infusion concentrations}

\subsubsection{Fluoride}

Fluoride was detected in all samples. Overall mean fluoride concentration was $0.68 \mathrm{mg} / \mathrm{l}$. The concentrations were below the lowest American bottled water limit of $1.4 \mathrm{mg} / \mathrm{l}$ determined for hot climates [31]; however, $2 \%$ of the samples were greater than the Turkish limit (1 mg/l) set for non-alcoholic beverages [32]. Loose and pot bag samples had similar mean/median concentrations $(0.672 / 0.666 \mathrm{mg} / \mathrm{l}$ vs. $0.676 / 0.653 \mathrm{mg} / \mathrm{l}$, respectively). However, instant bags had a higher mean/median concentration $(0.765 / 0.767 \mathrm{mg} / \mathrm{l})$. The difference was not significant with $t$-test between loose and instant bag $(p=0.31)$, and between pot bag and instant bag $(p=0.35)$ samples. Because of the large sample size difference between loose $(n=38)$ and instant bag $(n=6)$ groups, a nonparametric test was applied. The difference between the median values of loose and instant bag samples was significant with Mann-Whitney test at $p=0.10$. The difference among median concentrations of the most used three brands was not significant ( $p=0.54$, Kruskal-Wallis test).

Several studies were conducted on the F content of tea products sold in Turkey. Kalayci and Somer [17] measured infusion concentrations of 2.60 and $3.92 \mathrm{mg} / \mathrm{l}$ with 5 and $20 \mathrm{~min}$ extraction times, respectively. Water-soluble F content of Turkish teas was found to range from 55 to $127 \mu \mathrm{g} / \mathrm{g}$ [20]. These levels correspond to $0.55-1.27 \mathrm{mg} / \mathrm{l}$ when converted into infusion concentrations ( $2 \mathrm{~g}$ tea infused in $200 \mathrm{ml}$ of water). These concentrations are similar to the levels measured in this study. Hudaykuliev et al. [21] reported a range of F content for Turkish teas as $88-289 \mathrm{mg} / \mathrm{kg}$ which corresponds to $0.8-2.6 \mathrm{mg} / 1$ infusion concentrations with the assumption of water-soluble fraction is $90 \%$. Higher levels were reported from other parts of the world as $0.45-6.5 \mathrm{mg} / 1$ [7,10,11,18]. The highest concentrations $(4.8-7.3 \mathrm{mg} / \mathrm{l})$ occurred in brick tea infusions after $6 \mathrm{~h}$ of infusion [19].

\subsubsection{Trace metals}

Measurements showed that all metals had right-skewed concentration distributions. $\mathrm{Al}$ and $\mathrm{Mn}$ were the most abundant among the measured metals in black tea with 2.76 and $0.43 \mathrm{mg} / \mathrm{l}$ median concentrations, respectively. Descriptive statistics and values of the fitted distribution parameters are presented in Table 2. Median concentrations of the trace metals ranged from $0.11 \mu \mathrm{g} / \mathrm{l}$ for $\mathrm{Cd}$ to $89 \mu \mathrm{g} / \mathrm{l}$ for $\mathrm{Zn}$. While concentrations of As, $\mathrm{Cd}, \mathrm{Co}, \mathrm{Cu}, \mathrm{Ni}$, and $\mathrm{Zn}$ were below the Turkish nonalcoholic beverage [32] and the American bottled water [31] limits, $95 \%$ of the samples had $\mathrm{Al}$ concentrations higher than the Turkish non-alcoholic beverage limit of $2 \mathrm{mg} / \mathrm{l}$ [32]. Furthermore, $24 \%$ of measured Mn concentrations exceeded the American bottled water limit of $0.05 \mathrm{mg} / 1$ [31]. Kruskal-Wallis test pointed to a significant difference among loose, pot bag, and instant tea samples for only $\mathrm{Al}(p=0.025 ; p>0.30$ for the remaining metals). Mann-Whitney test showed that the difference was significant between loose and instant bag tea ( $p=0.007)$ with median values of 2.90 and $2.39 \mathrm{mg} / \mathrm{l}$, respectively, and between pot bags (median $=2.77 \mathrm{mg} / \mathrm{l}$ ) and instant bags $(p=0.055)$ for Al but not for the other metals. Comparison of metal concentrations among the three most consumed brands pointed that $\mathrm{Al}$ and $\mathrm{Sr}$ concentrations differed at the presumed significance level in this study. The difference was also significant, but at $p=0.10$, for $\mathrm{Cu}$; and $p>0.12$ for the remaining metals. Further investigation with Mann-Whitney test between tea brands resulted as while median $\mathrm{Sr}$ concentrations were different between Caykur $(5.02 \mu \mathrm{g} / \mathrm{l})$ and Dogus $(3.12 \mu \mathrm{g} / \mathrm{l})$, median Al concentrations were different between Caykur $(2.96 \mu \mathrm{g} / \mathrm{l})$ and Lipton $(2.56 \mu \mathrm{g} / \mathrm{l})$, and median Cu concentrations were different between Dogus $(9.5 \mu \mathrm{g} / \mathrm{l})$ and Lipton (14.1 $\mu \mathrm{g} / \mathrm{l})$.

Metal content of black tea sold in Turkey has not been studied extensively. Colak et al. [23] measured $\mathrm{Mn}, \mathrm{Fe}, \mathrm{Cu}, \mathrm{Zn}$, and $\mathrm{Ni}$ concentrations in three green tea samples. Average con- 
Table 2

Statistics of trace elemental concentrations in black tea

\begin{tabular}{|c|c|c|c|c|c|c|c|c|c|}
\hline Contaminant & Mean (S.E. $\left.{ }^{a, b}\right)$ & $95 \%$ CIAM $^{\mathrm{c}}$ & Median & S.D. ${ }^{d}$ & Min & Max & Skewness & Distribution & Parameter values \\
\hline Fluoride (mg/l) & $0.68(0.03)$ & $0.63-0.74$ & 0.67 & 0.20 & 0.34 & 1.48 & 1.13 & Logistic & Mean $=0.68 ;$ scale $=0.11$ \\
\hline Aluminum (mg/l) & $2.91(0.10)$ & $2.70-3.12$ & 2.76 & 0.72 & 1.66 & 5.35 & 1.35 & Lognormal & Mean $=2.91 ;$ S.D. $=0.68$ \\
\hline Arsenic $(\mu \mathrm{g} / 1)$ & $0.21(0.03)$ & $0.15-0.26$ & 0.14 & 0.19 & 0.002 & 0.73 & 1.17 & Weibull & Scale $=0.22 ;$ shape $=1.10$ \\
\hline Cadmium $(\mu g / 1)$ & $0.19(0.03)$ & $0.13-0.24$ & 0.11 & 0.19 & 0.02 & 0.79 & 1.97 & Lognormal & Mean $=0.19 ;$ S.D. $=0.21$ \\
\hline Chromium $(\mu \mathrm{g} / \mathrm{l})$ & $5.70(1.05)$ & $3.60-7.81$ & 3.48 & 7.41 & 1.58 & 43.2 & 3.83 & Lognormal & Mean $=5.11 ;$ S.D. $=3.78$ \\
\hline Cobalt $(\mu \mathrm{g} / \mathrm{l})$ & $0.35(0.04)$ & $0.27-0.43$ & 0.29 & 0.28 & 0.01 & 1.58 & 1.94 & Weibull & Scale $=0.38 ;$ shape $=1.266$ \\
\hline Copper $(\mu \mathrm{g} / \mathrm{l})$ & $17.5(1.86)$ & $13.7-21.2$ & 12.7 & 13.2 & 3.57 & 65.4 & 1.92 & Lognormal & Mean $=17.1 ;$ S.D. $=11.6$ \\
\hline Manganese $(\mu \mathrm{g} / \mathrm{l})$ & $572(56.1)$ & $459-684$ & 429 & 397 & 188 & 2105 & 1.80 & Gamma & $\begin{array}{l}\text { Location }=187 ; \text { scale }=339, \\
\text { shape }=1.13\end{array}$ \\
\hline Nickel $(\mu \mathrm{g} / \mathrm{l})$ & $16.6(1.00)$ & $14.6-18.6$ & 15.4 & 7.11 & 9.60 & 48.8 & 3.01 & Lognormal & Mean $=16.4 ;$ S.D. $=5.4$ \\
\hline Strontium $(\mu \mathrm{g} / \mathrm{l})$ & $5.47(0.80)$ & $3.86-7.07$ & 4.60 & 5.60 & 0.03 & 22.9 & 2.12 & Weibull & Scale $=5.52 ;$ shape $=0.99$ \\
\hline Zinc $(\mu \mathrm{g} / \mathrm{l})$ & $103(6.72)$ & $90-117$ & 89 & 47.5 & 39.2 & 253 & 1.30 & Lognormal & Mean $=103$; S.D. $=46.7$ \\
\hline
\end{tabular}

\footnotetext{
a Standard error.

b Statistics are based on $N=49$ for strontium and $N=50$ for the remaining.

c Confidence interval about the mean

d Standard deviation.

e Value of location parameter is 0 for Weibull distribution.
}

centrations were $1610,342,32,28$, and $26 \mathrm{mg} / \mathrm{kg}$. Cadmium and vanadium content of black tea was determined by Dundar and Saglam [22]. Mean concentrations of two types of tea were reported as 2.79 and $4.39 \mathrm{mg} / \mathrm{kg}$ for cadmium, and 0.65 and $2.30 \mathrm{mg} / \mathrm{kg}$ for vanadium.

In a review article, Wong et al. [19] reported that $\mathrm{Al}$ in tea infusions ranged between 0.7 and $6.0 \mathrm{mg} / \mathrm{l}$. Al concentrations measured in this study fall in this range. Fernandez et al. [30] analyzed elemental tea infusion concentrations in 22 loose and 2 instant bag tea samples for 11 metals. Range of $\mathrm{Al}$ concentrations was $1-10 \mathrm{mg} / \mathrm{l}$. Average concentrations for 5 -min infusion of $1.5 \mathrm{~g}$ of tea in $100 \mathrm{ml}$ of distilled water were $6.0,0.1,3.0$, 0.08 , and $0.2 \mathrm{mg} / \mathrm{l}$ for $\mathrm{Al}, \mathrm{Cu}, \mathrm{Mn}, \mathrm{Sr}$, and $\mathrm{Zn}$, respectively. These mean concentrations are substantially higher than the mean levels measured in this study ranging from approximately 2 times for $\mathrm{Al}$ and $\mathrm{Zn}$ to 13 times for $\mathrm{Sr}$. Some of the difference arises from the mass of tea infused per water volume, which is $50 \%$ higher than this study.

\subsection{Individual exposure and risks}

\subsubsection{Fluoride}

Exposures to contaminants were calculated as daily intake (mg/day) and daily intake per body weight (mg/(kg day)) which is chronic daily intake (CDI) in this study. CDI is used to calculate the risk levels due to the exposure by employing a no-adverse-effect-level. The USEPA lists [28] a Reference Dose (RfD) for objectionable dental fluorosis as $6 \times 10^{-2} \mathrm{mg} /(\mathrm{kg}$ day). Cao et al. [18] reported that an increased risk occurs for bone effect at a total intake of $6 \mathrm{mg} \mathrm{F} /$ day. Whyte

Table 3

Descriptive statistics for individual exposure and risk

\begin{tabular}{|c|c|c|c|c|c|c|c|}
\hline & Mean (S.E. $\left.{ }^{a}\right)$ & $95 \%$ CIAM $^{\mathrm{b}}$ & Median & S.D. ${ }^{\mathrm{c}}$ & Min & Max & Skewness \\
\hline Fluoride $\mathrm{DI}^{\mathrm{d}}(\mathrm{mg} /$ day $)$ & $0.34(0.04)$ & $0.27-0.41$ & 0.25 & 0.25 & 0.04 & 1.13 & 0.93 \\
\hline Fluoride $\mathrm{CDI}^{\mathrm{e}}$ (ng/(kg day)) & $5.0(0.06)$ & $3.9-6.2$ & 3.3 & 4.1 & 0.8 & 15 & 1.08 \\
\hline Fluoride $\mathrm{HQ}^{\mathrm{f}}\left(\times 10^{3}\right)$ & $84(10)$ & $65-100$ & 55 & 68 & 13 & 250 & 1.08 \\
\hline Aluminum HQ $\left(\times 10^{3}\right)$ & $21(2.5)$ & $16-26$ & 16 & 18 & 4.1 & 73 & 1.54 \\
\hline Arsenic HQ $\left(\times 10^{3}\right)$ & $5.5(1.0)$ & $3.6-7.5$ & 2.4 & 6.8 & 0.1 & 26 & 1.59 \\
\hline Arsenic $R\left(\times 10^{6}\right)$ & $2.5(0.4)$ & $1.6-3.4$ & 1.1 & 3.1 & 0.02 & 12 & 1.59 \\
\hline Manganese HQ $\left(\times 10^{3}\right)$ & $28(4.0)$ & $20-36$ & 18 & 28 & 4.0 & 131 & 2.24 \\
\hline Nickel HQ $\left(\times 10^{3}\right)$ & $6.0(0.6)$ & $4.7-7.2$ & 4.4 & 4.5 & 1.0 & 18 & 1.05 \\
\hline Strontium HQ $\left(\times 10^{5}\right)$ & $6.7(1.4)$ & $4.0-9.5$ & 2.9 & 9.6 & 0.03 & 50 & 2.70 \\
\hline Zinc HQ $\left(\times 10^{3}\right)$ & $2.6(0.3)$ & $1.9-3.2$ & 1.6 & 2.4 & 0.4 & 11 & 1.71 \\
\hline
\end{tabular}

\footnotetext{
${ }^{a}$ Standard error.

${ }^{\mathrm{b}}$ Confidence interval about the mean.

c Standard deviation.

d Daily intake.

${ }^{\mathrm{e}}$ Chronic daily intake.

${ }^{\mathrm{f}}$ Hazard quotient.
} 
et al. [7] considered $10 \mathrm{mg} \mathrm{F} /$ day as the threshold level for "preclinical skeletal fluorosis." Descriptive statistics of individual exposure and risk (HQ) estimations, based on the RfD, are shown in Table 3. None of the participants had exposures that may cause a significant risk ( $\max . \mathrm{HQ}=0.25<1$ ) for objectionable dental fluorosis, not to mention the bone effect or skeletal fluorosis from $\mathrm{F}$ intake by drinking black tea.

\subsubsection{Trace metals}

Individual exposure and risk estimates for metals are presented in Table 3. CDI for Al ranged from 4 to $73 \mu \mathrm{g} /(\mathrm{kg}$ day). The World Health Organization (WHO) recommends a tolerable weekly intake of $7 \mathrm{mg} / \mathrm{kg}$ body weight [33]. Noncarcinogenic risk levels were estimated using this value in place of RfD since no RfD value was listed by the USEPA [28]. The risk estimates showed that there were no significant risks involved in black tea intake as the maximum HQ value was less than one-tenth of the demarcation value. Researchers have concluded that neither dietary intake [34] nor intake from alum treated drinking water [35] is likely to contribute to Alzheimer's disease in contrast to the link found in an epidemiological study [8]. In this study, average, standard deviation, and maximum individual daily intake values were calculated as $1.4,1.1$, and $5.1 \mathrm{mg} /$ day, respectively. Taking $25 \mathrm{mg} /$ day [34] as daily adult intake of $\mathrm{Al}$ from diet, tea would correspond to 6 and $20 \%$ at the mean and maximum lev- els, respectively. Stauber et al. [35] estimated that contribution of tea to the total $\mathrm{Al}$ intake was $53 \%$ which was comparable to $41 \%$ for food in a total dietary intake of $3.2 \mathrm{mg} /$ day. While the mean daily intake estimated in this study corresponds to $44 \%$ of that total intake, the maximum value in this study is 1.6 times the total dietary intake of $3.2 \mathrm{mg} /$ day. Fernandez et al. [30], on the other hand, assumed an average daily dietary intake (ADDI) of $5 \mathrm{mg} /$ day. Nonetheless, $\mathrm{Al}$ intake from black tea constituted an important portion of the daily total dietary intake, but the risk levels were not significant.

Tea is, also, an important source of Mn. Fernandez et al. [30] estimated that a consumption of 2.95 cups $(50-\mathrm{ml}) /$ day would constitute $10 \%$ and $18 \%$ of the ADDI ( $4 \mathrm{mg} /$ day) for loose and instant tea, respectively. The mean $(0.25 \mathrm{mg} /$ day $)$ and the maximum $(1.2 \mathrm{mg} /$ day $)$ daily intake values estimated in this study are $6.25 \%$ and $30 \%$ of the ADDI, respectively. The HQ values calculated for Mn did not point to significant noncarcinogenic risk values in this study.

In general, one in million $\left(10^{-6}\right)$ is considered as the acceptable carcinogenic risk level in environmental risk assessment [36]. However, this acceptable level may change according to environmental policies and may be as high as $10^{-4}[37,38]$ as in the case of As. Arsenic concentrations measured in this study were at levels that would result in moderately high carcinogenic risk $(R)$ levels. Average and maximum $R$ values were $2.5 \times 10^{-6}$
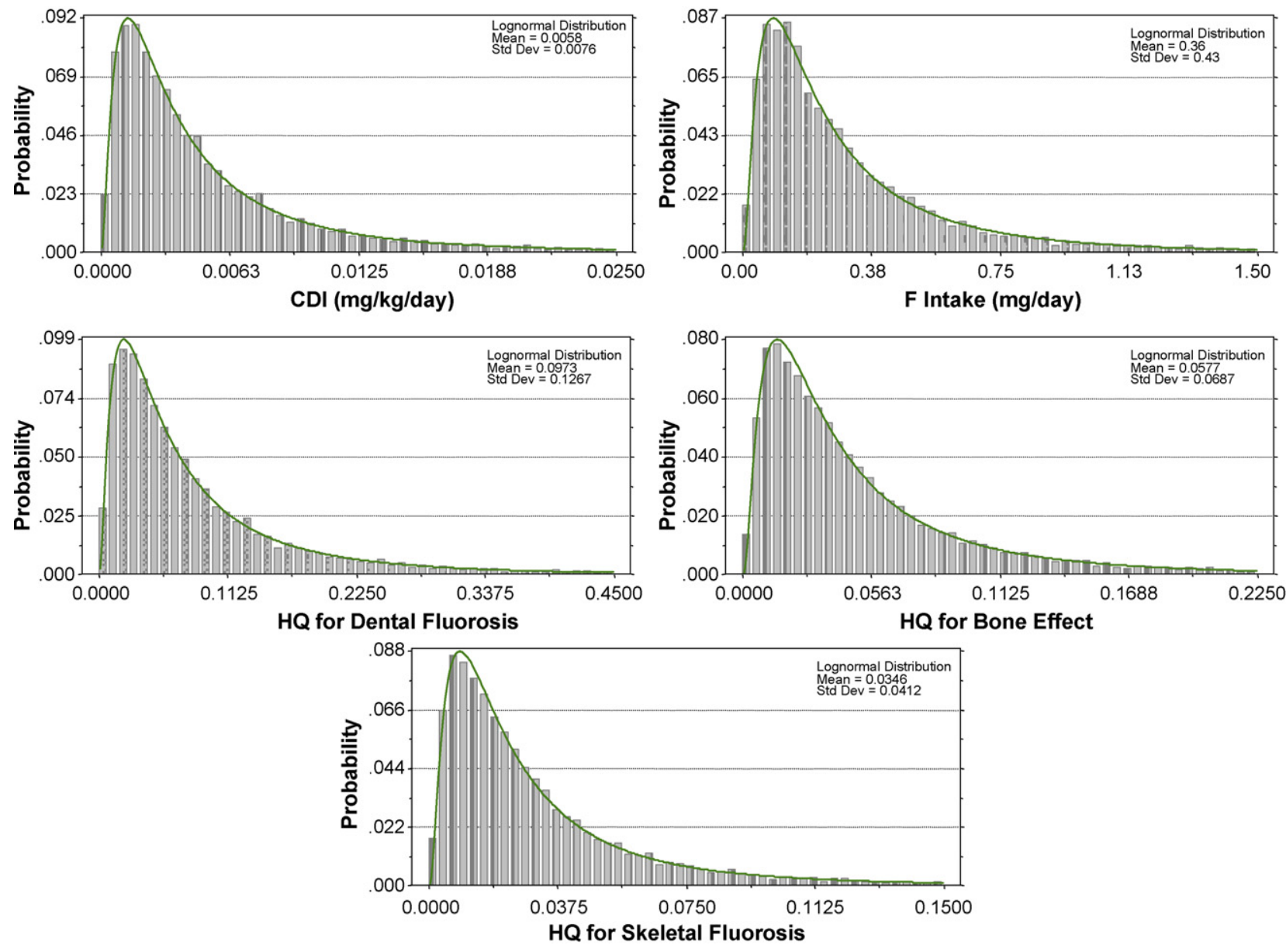

Fig. 2. Population CDI, intake, and HQ distributions for fluoride. 
and $1.2 \times 10^{-5}$, respectively, falling between the two demarcation levels. All noncarcinogenic risk levels for As were well below the demarcation value of 1 as in the cases of $\mathrm{Cd}, \mathrm{Ni}, \mathrm{Sr}$, and $\mathrm{Zn}$.

\subsection{Population exposure and risks}

\subsubsection{Fluoride}

Monte Carlo simulation was carried out to estimate distributions of exposure and risk for İzmir population using the fitted distributions of the input variables (see Fig. 1 and Table 2) in the exposure and risk equations (see Section 2.5). The resulting frequency histograms from the simulation for fluoride and the best fitting distributions are presented in Fig. 2. Lognormal distribution was the best fitting distribution to all output variables. None of the risks for dental fluorosis, bone effect, and skeletal fluorosis due to tea intake could be considered high enough to cause a concern for the population. Sensitivity analysis revealed that among the three input variables (fluoride concentration, body weight, and daily tea intake), daily tea intake has the largest effect on the outcomes, exposure and risk. The sensitivity level, measured by rank correlation of an input to the output, was 0.89 for daily tea intake, and approximately 0.30 for the remaining two variables.

Therefore, daily tea intake was analyzed according to participant characteristics (age, sex, education level) and habits (source of tea water, tea type, tea brand, daily drinking water intake) on individual level. Daily tea intake (DI) was found not to differ between males and females. Participants were pooled into three age groups, $<15,15-35$, and $>35$ years, with respective median daily tea intake values of $0.075,0.30$, and $0.75 \mathrm{l} /$ day. Kruskal-Wallis test showed that at least one group had a different median, and Mann-Whitney test showed that all differences were significant. Furthermore, correlation between age group and DI variables was significant $(p<0.001)$ with Spearman's Rho value of 0.54 . Participants were pooled into two education levels (primary + middle school and high school or higher) with median DI values of 0.15 and $0.561 /$ day, respectively. The difference was significant $(p=0.032)$ with Mann-Whitney test. Statistical tests showed that DI did not differ with source of tea water $(p=0.11)$, tea type $(p=0.33)$, and tea brand $(p=0.26)$. Mann-Whitney test was applied to test the differences between each of the groups in tea type and brand categories. Results showed that the difference was significant only between the brands of Caykur and Lipton with median values of 0.15 and $0.75 \mathrm{l} /$ day, respectively. No relation was observed between daily tea intake and daily drinking water intake, analyzed by simple linear regression on log-transformed values $(r=0.03, p=0.83)$. In summary, people's exposure to contaminants in tea infusions was increased with age and education level because their tea consumption was increased with increase in these variables.

\subsubsection{Trace metals}

Simulation results for the three metals with the highest HQ values, and carcinogenic risk for As are presented as frequency distributions in Fig. 3. The figure also includes the best fitting
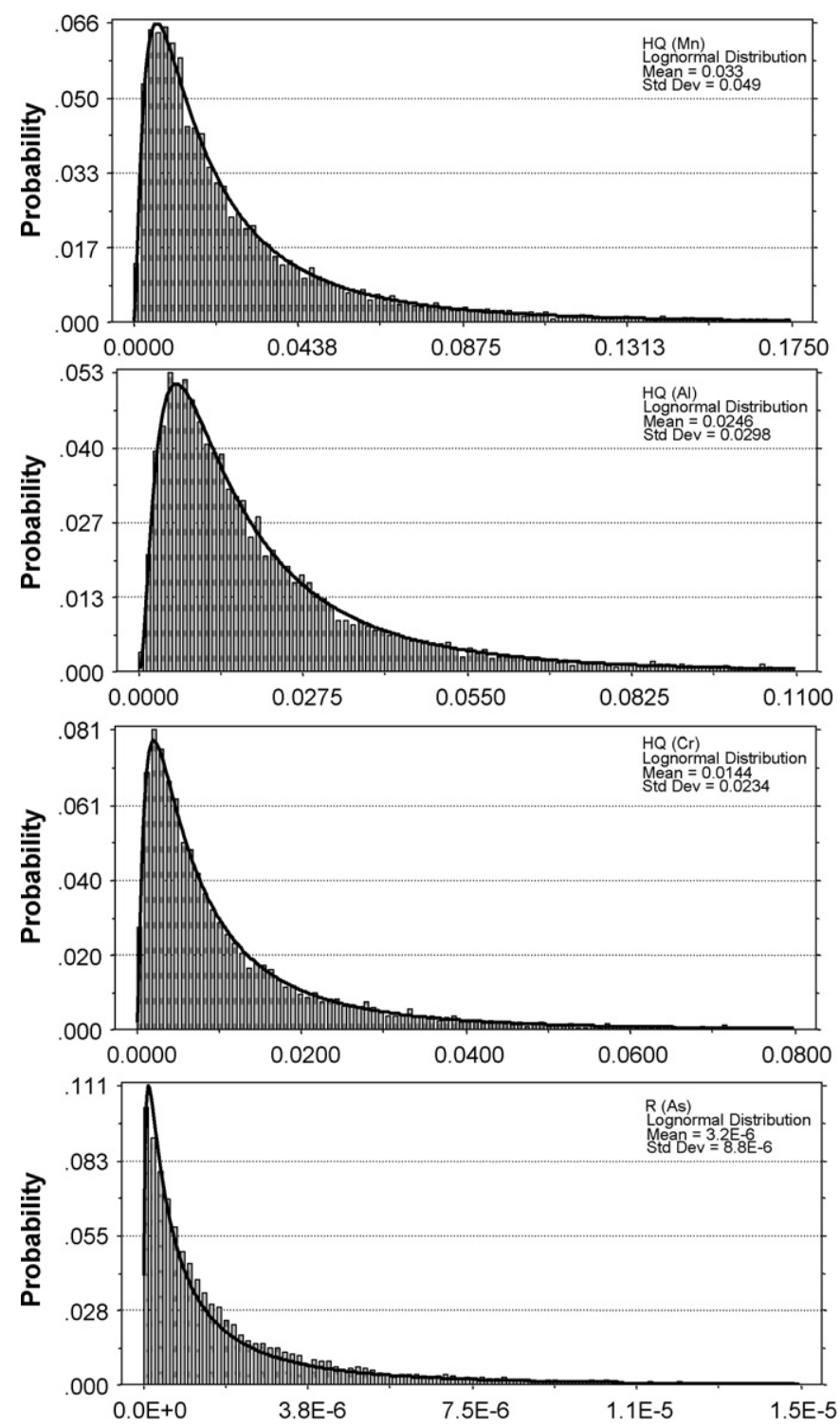

Fig. 3. Population health risk distributions for trace metals.

distribution and its parameter values for the four metals. Lognormal distribution fitted the best to all risk distributions. The three metals are placed in descending HQ range in the figure. Ninetyfifth percentile $\mathrm{HQ}$ values for $\mathrm{Mn}, \mathrm{Al}$, and $\mathrm{Cr}$ were $0.11,0.08$, and 0.05 , respectively. Therefore, we may conclude that according to population noncarcinogenic risk distributions, the risk levels were not significant for any of the ten metals evaluated. However, carcinogenic risk for arsenic was of concern since both of the median $\left(1.2 \times 10^{-6}\right)$ and 95 th percentile $\left(1.0 \times 10^{-5}\right) R$ values are $>10^{-6}$; but not unacceptable, $<10^{-4}$.

Results of sensitivity analyses showed that daily tea intake was the most influencing variable on HQ for all of the three metals presented in Fig. 3. Carcinogenic risk, however, was the most sensitive to the As concentrations (Table 4). Results, in terms of environmental health management, imply that controlling both As concentrations and daily tea intake would be effective in risk mitigation efforts. 
Table 4

Results of Monte Carlo simulation sensitivity analysis

\begin{tabular}{llll}
\hline Forecast & \multicolumn{2}{l}{ Sensitivity measured by rank correlation } \\
\cline { 2 - 4 } & Daily tea intake & Contaminant concentration & Body weight \\
\hline HQ (Al) & 0.92 & 0.23 & -0.28 \\
HQ (Cr) & 0.76 & 0.56 & -0.23 \\
HQ (F) & 0.89 & 0.30 & -0.27 \\
HQ (Mn) & 0.79 & 0.49 & -0.25 \\
$R$ (As) & 0.60 & 0.73 & -0.19 \\
\hline
\end{tabular}

Our previous research [39] had shown that carcinogenic risk levels due to oral exposure to drinking water arsenic in İzmir were high with $7.9 \times 10^{-5}, 3.1 \times 10^{-4}$, and $1.4 \times 10^{-3}$ at median, mean, and 95th percentile levels, respectively. Therefore, As in black tea would add to the carcinogenic risk concerns already high for ingestion of drinking water.

\section{Conclusion}

Fluoride intake from drinking loose, instant bag, or pot bag teas sold in İzmir, Turkey, was not high enough to cause significant risk for dental fluorosis, not to mention the bone effect or skeletal fluorosis. Exposure to none of the evaluated 10 trace metals via tea intake, including aluminum with regards to Alzheimer's disease, were not at levels to cause concern for noncarcinogenic risks. However, arsenic was a concern, as the estimated carcinogenic risk levels were greater than one in million.

\section{Acknowledgements}

Staff of Environmental Research Center, İzmir Institute of Technology, is acknowledged for the analysis of trace metals. Dr. Ahmet E. Eroglu and Ms. Asli Erdem of Department of Chemistry are gratefully acknowledged for fluoride analyses. Contributions of Ms. Nihan Kiymet and Ms. Özge Top in fluoride risk assessment are also acknowledged.

\section{References}

[1] S.T. Shi, Z.Y. Wang, T.J. Smith, J.Y. Hong, W.F. Chen, C.T. Ho, C.S. Yang, Effects of green tea and black tea on 4-(methylnitrosamine)-1-(3-pyridyl)1-butanone bioactivation, DNA methylation and lung tumorigenesis in A/J mice, Cancer Res. 54 (1994) 4641-4647.

[2] Z.Y. Wang, M.T. Huang, Y.R. Lou, J.G. Xie, K.R. Reuhl, H.L. Newmark, C.T. Ho, C.S. Yang, A.H. Conney, Inhibitory effects of black tea, green tea, decaffeinated black tea and decaffeinated green tea on ultraviolet B light induced skin carcinogenesis in 7,12-dimethylbenz $(a)$ anthracene-initiated SKH-1 mice, Cancer Res. 54 (1994) 3428-3435.

[3] M.G.L. Hertog, E.J.M. Feskens, P.C.H. Hollman, M.B. Katan, D. Kromhout, Dietary antioxidant flavonoids and risk of coronary heart disease: the Zutphen Elderly Study, Lancet 342 (1993) 1007-1011.

[4] J.P. Henry, P. Stephens-Larson, Reduction of chronic psychosocial hypertension in mice by decaffeinated tea, Hypertension 6 (1984) 437-444.

[5] A. Rasheed, M. Haider, Antibacterial activity of Camellia sinesis extracts against dental caries, Arch. Pharmacol. Res. 21 (1998) 348-352.

[6] J. Cao, X. Bai, Y. Zhao, J. Liu, D. Zhou, S. Fang, M. Jia, J. Wu, The relationship of fluorosis and brick tea drinking in Chinese Tibetans, Environ. Health Perspect. 104 (1996) 1340-1343.
[7] M.P. Whyte, K. Essmyer, F.H. Gannon, W.R. Reinus, Skeletal fluorosis and instant tea, Am. J. Med. 118 (2005) 78-82.

[8] D.R.C. McLachlan, Aluminum and the risk for Alzheimer's disease, Environmetrics 6 (1995) 233-275.

[9] K.F. Fung, Z.Q. Zhang, J.W.C. Wong, M.H. Wong, Fluoride contents in tea and soil from tea plantations and the release of fluoride into tea liquor during infusion, Environ. Pollut. 104 (1999) 197-205.

[10] P. Gulati, V. Singh, M.K. Gupta, V. Vaidya, S. Dass, S. Prakash, Studies on the leaching of fluoride in tea infusions, Sci. Total Environ. 138 (1993) 213-222.

[11] S.C. Lung, P. Hsiao, K. Chiang, Fluoride concentrations in three types of commercially packed tea drinks in Taiwan, J. Expo. Anal. Environ. Epidemiol. 13 (2003) 66-73.

[12] M.H. Wong, Z.Q. Zhang, J.W.C. Wong, C.Y. Lan, Trace metal contents $(\mathrm{Al}, \mathrm{Cu}$ and $\mathrm{Zn}$ ) of tea: tea and soil from two plantations, and tea products from different provinces of China, Environ. Geochem. Health 20 (1998) 87-94.

[13] S. Nookabkaew, N. Rangkadilok, J. Satayavidad, Determination of trace elements in herbal tea products and their infusions consumed in Thailand, J. Agric. Food Chem. 54 (2006) 6939-6944.

[14] M.P. Whyte, Fluoride levels in bottled teas, Am. J. Med. 119 (2006) 189-190.

[15] W.S. Shu, Z.Q. Zhang, C.Y. Lan, M.H. Wong, Fluoride and aluminum concentrations of tea plants and tea products from Sichuan Province, PR China, Chemosphere 52 (2003) 1475-1482.

[16] Y. Lu, W. Guo, X. Yang, Fluoride content in tea and its relationship with tea quality, J. Agric. Food Chem. 52 (2004) 4472-4476.

[17] S. Kalayci, G. Somer, Factors affecting the extraction of fluoride from tea: application to three samples, Fluoride 36 (2003) 267-270.

[18] J. Cao, Y. Zhao, Y. Li, H.J. Deng, J. Yi, J.W. Liu, Fluoride levels in various black tea commodities: measurement and safety evaluation, Food Chem. Toxicol. 44 (2006) 1131-1137.

[19] M.H. Wong, K.F. Fung, H.P. Carr, Aluminum and fluoride contents of tea, with emphasis on brick tea and their health implications, Toxicol. Lett. 137 (2003) 111-120.

[20] S. Tokalioglu, U. Sahin, S. Kartal, Determination of fluoride and some metal ion levels in the drinking waters in Kayseri Province, Turk. J. Chem. 25 (2001) 113-121.

[21] Y. Hudaykuliev, M. Tastekin, E.S. Poyrazoglu, E. Baspinar, Y.S. Velioglu, Variables affecting fluoride in Turkish black tea, Fluoride 38 (2005) 38-43.

[22] M.S. Dundar, H.B. Saglam, Determination of cadmium and vanadium in tea varieties and their infusions in comparison with two infusion processes, Trace Elem. Electrolytes 21 (2004) 60-63.

[23] H. Colak, M. Soylak, O. Turkoglu, Determination of trace metal content of various herbal and fruit teas produced and marketed in Turkey, Trace Elem. Electrolytes 22 (2005) 192-195.

[24] USEPA, Guidelines for Carcinogen Risk Assessment, NCEA-F-0644, Review Draft, Risk Assessment Forum, Washington, DC, 1999.

[25] USEPA, Guidelines for Exposure Assessment, EPA/600/Z-92/001, Risk Assessment Forum, Washington, DC, 1992.

[26] D.R. Patrick, Risk assessment and risk management, in: D.R. Patrick (Ed.), Toxic Air Pollution Handbook, Van Nostrand Reinhold, New York, 1994, p. 347.

[27] USEPA, Guidance for Performing Aggregate Exposure and Risk Assessments, Office of Pesticide Programs, Washington, DC, 1999.

[28] IRIS, Integrated Risk Information System, US Environmental Protection Agency, Cincinnati, OH. http://www.epa.gov/iris, 2007 (accessed 2007).

[29] USEPA, Guiding Principles for Monte Carlo Analysis, EPA/630/R-97/001, Risk Assessment Forum, Washington, DC, 1997.

[30] P.L. Fernandez, F. Pablos, M.J. Martin, A.G. Gonzalez, Multi-element analysis of tea beverages by inductively coupled plasma atomic emission spectrometry, Food Chem. 76 (2002) 483-489.

[31] US FDA, Bottled Water (21-CFR-165.110), Department of Health and Human Services, United States Food and Drug Administration, 2003.

[32] TC TKB, Türk Gıda Kodeksi, Gıda Maddelerinde Belirli Bulaşanların Maksimum Seviyelerinin Belirlenmesi Hakkında Tebliğ, Tebliğ No. 2002/63, TC Tarım ve Köyişleri Bakanlığı, Ankara, Turkey, 2002. 
[33] FAO/WHO, Aluminum. in: Evaluation of Certain Food Additives and Contaminants, 32. Report of the Joint FAO/WHO Expert Committee on Food Additives, WHO, Geneva, 1989, pp. 28-31.

[34] M.G. Soni, S.M. White, W.G. Flamm, G.A. Burdock, Safety evaluation of dietary aluminum, Regul. Toxicol. Pharmacol. 33 (2001) 66-79.

[35] J.L. Stauber, T.M. Florence, C.M. Davies, M.S. Adams, S.J. Buchanan, Bioavailability of $\mathrm{Al}$ in alum-treated drinking water, J. Am. Water Works Assoc. 91 (1999) 84-93.

[36] P. Kavcar, M. Odabasi, M. Kitis, F. Inal, S.C. Sofuoglu, Occurrence, oral exposure and risk assessment of volatile organic compounds in drinking water for Izmir, Water Res. 40 (2006) 3219-3230.
[37] USEPA, Water quality standards, establishment of numeric criteria for priority toxic pollutants for the State of California. http://www.epa.gov/EPAWATER/2000/May/Day-18/w11106.htm, 2000 (accessed 2007).

[38] WHO, Guidelines for Drinking-water Quality, third ed., vol. 1, Recommendations, World Health Organization, Geneva, 2004.

[39] S.C. Sofuoglu, P. Kavcar, Assessment of exposure and risk associated with drinking water in İzmir, Report (TÜBİTAK, İÇTAG-Ç077), The Scientific and Technical Research Council of Turkey, Ankara, 2005. 